University of Wollongong

Research Online

Faculty of Engineering and Information

Faculty of Engineering and Information

Sciences - Papers: Part A

Sciences

$1-1-2014$

Performance based seismic assessment of bridges designed according to Canadian Highway Bridge Design Code

M Neaz Sheikh

University of Wollongong, msheikh@uow.edu.au

Frederic Legeron

Universita de Sherbrooke

Follow this and additional works at: https://ro.uow.edu.au/eispapers

Part of the Engineering Commons, and the Science and Technology Studies Commons

Research Online is the open access institutional repository for the University of Wollongong. For further information contact the UOW Library: research-pubs@uow.edu.au 


\title{
Performance based seismic assessment of bridges designed according to Canadian Highway Bridge Design Code
}

\author{
Abstract \\ Recent research efforts have focused on the development of performance based seismic design \\ methodologies for structures. However, the seismic design rules prescribed in the current Canadian \\ Highway Bridge Design Code (CHBDC) is based largely on force based design principles. Although a set \\ of performance requirements (performance objectives) for different return period earthquake events have \\ been specified, there is no explicit requirement in the CHBDC to check the attainment of such \\ performance objectives for the designed bridges. Also, no engineering parameters have been assigned to \\ the specified performance objectives. This paper correlates seismic performance objectives (both \\ qualitative and quantitative) with engineering parameters, based on the data collected from published \\ experimental investigations and field investigation reports of recent earthquakes. A simple method has \\ been developed and validated with experimental results for assessing the performance of bridges \\ designed according to CHBDC. It has been found that the design rules prescribed in CHBDC do not \\ guarantee that specified multiple seismic performance objectives can be achieved. An implicit seismic \\ design rule in the form of performance response modification factor has been outlined for the \\ performance based seismic design of bridges.
}

\section{Keywords}

bridges, design, designed, performance, according, seismic, canadian, code, highway, assessment, bridge

\section{Disciplines}

Engineering | Science and Technology Studies

\section{Publication Details}

Sheikh, M. Neaz. \& Legeron, F. (2014). Performance based seismic assessment of bridges designed according to Canadian Highway Bridge Design Code. Canadian Journal of Civil Engineering, 41 (9), 777-787. 


\title{
PERFORMANCE BASED SEISMIC ASSESSMENT OF BRIDGES DESIGNED ACCORDING TO CANADIAN HIGHWAY BRIDGE DESIGN CODE
}

\author{
M. Neaz Shéikh ${ }^{1}$ and Frédéric Légeron ${ }^{2, *}$
}

\author{
Affiliation: \\ ${ }^{1}$ Senior Lecturer, School of Civil, Mining and Environmental Engineering, University of \\ Wollongong, Australia \\ ${ }^{2}$ Professor of Civil Engineering, Université de Sherbrooke, Canada
}

\section{Correspondence:}

Name: F. Légeron

Address: Department of Civil Engineering

Université de Sherbrooke

2500 boul. de l'Université,

Sherbrooke, Québec, J1K 2R1

E-mail: Frederic.Legeron@USherbrooke.ca

Telephone: (819) 821-7395

Fax: (819) 821-7974

* Corresponding author 


\title{
PERFORMANCE BASED SEISMIC ASSESSMENT OF BRIDGES DESIGNED ACCORDING TO CANADIAN HIGHWAY BRIDGE DESIGN CODE
}

\author{
M. Neaz Sheikh ${ }^{1}$ and Frederic Legeron ${ }^{2}$ \\ ${ }^{1}$ Senior Lecturer, School of Civil, Mining and Environmental Engineering, University of \\ Wollongong, Australia \\ ${ }^{2}$ Professor of Civil Engineering, Université de Sherbrooke, Canada
}

\begin{abstract}
Recent research efforts have focused on the development of performance based seismic design methodologies for structures. However, the seismic design rules prescribed in the current Canadian Highway Bridge Design Code (CHBDC) is based largely on force based design principles. Although a set of performance requirements (performance objectives) for different return period earthquake events have been specified, there is no explicit requirement in the CHBDC to check the attainment of such performance objectives for the designed bridges. Also, no engineering parameters have been assigned to the specified performance objectives. This paper correlates seismic performance objectives (both qualitative and quantitative) with engineering parameters, based on the data collected from published experimental investigations and field investigation reports of recent earthquakes. A simple method has been developed and validated with experimental results for assessing the performance of bridges designed according to CHBDC. It has been found that the design rules prescribed in CHBDC do not guarantee that specified multiple seismic performance objectives can be achieved. An implicit seismic design rule in the form of performance response modification factor has been outlined for the performance based seismic design of bridges.
\end{abstract}

Keywords: seismic, bridges, performance objectives, design, assessment, codes. 


\section{INTRODUCTION}

Integrity of the transportation network is vital for the sustained development of a modern society. Bridges are essential parts of the transportation system worldwide. The closure of important bridges due to damage or collapse in the event of an earthquake can disrupt the total transportation network. Extensive research investigations have been conducted on the seismic behaviour of reinforced concrete bridges after the 1971 San Fernando earthquake. Also, past earthquakes revealed several deficiencies in the design and detailing of bridges (Saiidi 2011). Significant improvements in both design practices and analytical methods have been achieved. Field investigation reports of recent earthquakes (Kawashima and Unjoh 1997; Basöz et al. 1999; Hsu and Fu 2004) suggest that modern engineered bridges performed reasonably well, while damages were mainly observed in the older bridge constructions that were designed based on inadequate or no seismic requirements. Damages to modern bridges were mainly in the form of cracking of concrete and spalling of concrete cover. However, such damages (or inadequate performances) in important bridges can cause considerable economic losses.

The seismic design rules in the current Canadian Highway Bridge Design Code, CHBDC (CAN/CSA-S6-06) were developed based largely on force based design principles. The seismic force level corresponding to elastic response to a design acceleration response spectrum for a soil site class is calculated based on an estimate of the elastic stiffness of the structure. This elastic force is then modified by a response modification factor $(R)$ for an assumed ductility capacity of the bridge pier and an importance factor, $(I)$ for the expected performance (all traffic immediate use, emergency vehicles immediate use, repairable damage, and reconstruction) of the bridge in the event of three levels of earthquake events (small to moderate, design, and large earthquake events). The design rules in CHBDC do not necessarily ensure the future performance of the bridge. A single $R$-factor recommended in the code may generally be suitable for a single level of design; seismic design for multiple performance levels may require a set of $R$-factors, each associated with an individual performance level. The $I$-factor included in the code was chosen arbitrarily to adjust the seismic force 
level for important bridges. However, the arbitrarily chosen $I$-factor should be dependent on the seismicity and the properties of the bridge.

Recent research efforts have focused on the development of performance based seismic design and assessment procedures. The main objective is the coupling of structural performances with earthquake ground motions. Proper implementation of performance based seismic design rules will enable to reduce loss of lives, minimize economic losses in earthquakes, and decrease the need for emergency services during and after an earthquake (Floren and Mohammadi 2001). The structural engineering community has proposed several methodologies for performance based seismic design of new bridges and seismic retrofitting/upgrading of existing bridges (Sheikh, et al. 2010; Lehman et al. 2004). Seismic design codes are in transition towards the full implementation of performance based seismic design procedures. The seismic performance objectives, considering the level of importance (lifeline, emergency-route, and other) of the bridge, have been specified in the commentary of CHBDC (Table 1). Like other bridge design codes (AASHTO, 2007; AS 5100, 2004; EC8, 1994), CHBDC does not require design engineers to explicitly check the seismic performance of the designed bridges. Although damages are anticipated in future earthquakes (Table 1), there is no consideration of the extent of the damage in the design procedure. Moreover, performance levels specified in CHBDC are very descriptive. CHBDC does not provide clear guidelines to check whether such performance objectives are achieved, although there are only a few published articles available on this issue. It is therefore assumed that the set of design rules provided in the CHBDC are sufficient to ensure that the specified seismic performance objectives are achieved. It is noted that the public review version of Canadian Highway Bridge Design Code CAN/CSA-S6-14 (2013) includes both force-based and performance-based design approaches. In the recommended performance-based design approach, some requirements for different performance categories have been outlined.

This paper reveals that the current design rules suggested in CHBDC (CAN/CSA-S6-06) do not automatically satisfy the specified seismic performance objectives. In this paper, qualitative and quantitative performance levels are correlated with engineering parameters (Section 2), which enables engineers to check the seismic performance of designed bridges. Also, repair techniques have been 
specified for all performance levels. A simple modelling method based on nonlinear dynamic pushover analyses has been outlined in Section 3. The model has been fully validated with experimental results. Using the developed modelling method, seismic performance of bridges designed according to CHBDC has been investigated and limitations of design rules in CHBDC in meeting the specified seismic performance requirements have been suggested (Section 4). Finally, an implicit seismic design rule which can fulfil the seismic performance requirements has been outlined (Section 5).

\section{SEISMIC PERFORMANCE AND POST-EARTHQUAKE SERVICEABILITY OF BRIDGES}

Seismic design rules in the current CHBDC (CSA 2006) do not explicitly consider seismic demand versus seismic capacity of bridges at different damage states. Hence, for the bridges designed according to CHBDC, the actual inelastic capacity (or performance) is not known during the design phase of the bridge. However, performance based seismic engineering for bridges requires that bridges achieve specific performances in given hazard levels. For the proper implementation of performance based seismic design, each performance objective should be co-related with engineering parameter (e.g., cracking of concrete, yielding of reinforcement, spalling of concrete cover, reinforcing bar buckling and fracture, crushing of concrete, and loss of strength). Such damage parameters can be better measured at component levels (Hose et al. 2000; Lehman et al. 2004), especially for bridges. In general, inelastic action in bridges is expected to occur in the piers, not in beams or foundations. Hence, the seismic performance of a bridge is largely dependent on the inelastic capacity of the bridge piers.

The authors propose four different performance levels or limit states (1A, 1B, 2 and 3$)$ for bridges (Table 2) which could be directly incorporated in the next generation CHBDC. Table 2 is based on the observed damages in recent earthquakes (Basöz et al. 1999, Kawashima and Unjoh 1997; Hsu Fu 2004) and the reported data from experimental investigations on a large number of bridge piers (Berry 
et al. 2004). The proposed limit states (LS) are congruent with the definitions of LS presented in Hose et al. (2000), Kowalsky (2000), Floren and Mohammadi (2001), and Lehman et al. (2004).

Up to the LS-1A, the response is elastic with small displacement amplitude. No cracking of concrete is expected to occur and no post-earthquake repair is necessary. Beyond LS-1A and up to LS-1B, the concrete may crack, but the damage should be minor and easily repairable. There might be few crack openings, but the capacity of the pier shall not be affected noticeably and the bridge shall remain fully operational. Moderate structural damage may occur up to LS-2. However, the bridge may remain functional for emergency and defence/security vehicles only. Up to LS-3, significant structural damage is expected to occur but the bridge should not collapse. The bridge will not be useable after the earthquake and extensive repairs may be required. Such repair may not be always economically feasible and reconstruction might sometimes be necessary.

The above descriptions of LS of bridges have been summarized in Figure 1. It can be observed that the region between LS-2 and LS-3 has been divided into two regions: Repairable damage and Reconstruction. Experimental results for engineering parameters to clearly distinguish between repairable damage and reconstruction are not currently available. This may probably be dependent on the type of the bridge. Therefore, a displacement capacity midway between LS-2 and LS-3 has been chosen as the limiting displacement between repairable damage and re-construction (Figure 1).

\section{MODELLING FOR SEISMIC PERFORMANCE ASESSMENT OF BRIDGES}

Sophisticated numerical analysis that includes inelastic response of bridge piers, joints, and beams may require fully characterizing the cyclic response of the bridge. However, the seismic safety of the bridges depends largely on the inelastic response (or damage) of the of the bridge piers (Hose et al. 2000; Lehman et al. 2004). Hence, nonlinear static analysis procedure can be adopted for the response of the bridge pier and the identification of local damage parameters (Table 2) under different levels of earthquake shaking. Such analysis may reasonably simulate the behaviour of the bridge supported only by piers. 
A simplified seismic assessment method for seismic performance assessment of bridge piers based fully on displacement principle, adopting nonlinear monotonic static analysis approach, has been developed in Sheikh and Legeron (2012). The method adopts local approach for direct comparison of the performance of bridge piers with performance LS described in the earlier section. The method takes into account the nonlinear behaviour of materials including the confinement effect from lateral reinforcement. The displacement components that contribute to the total tip displacement include bending and shear deformation along the pier length together with deformation due to slip of the longitudinal reinforcement at the joint. A brief description of the method has been presented herein.

(a) Nonlinear material model for reinforced concrete

Realistic constitutive model for highly nonlinear reinforced concrete is complex, as the nonlinearity arises from the constituent concrete and reinforcement should be appropriately combined. The nonlinear model of reinforced concrete consists of constitutive laws of concrete and reinforcement.

\section{Constitutive law of concrete}

The realistic constitutive law of concrete needs to take into account the effect of confinement on the overall stress-strain behaviour of concrete. In the method developed herein, the uniaxial confined concrete model proposed in Legeron and Paultre (2003) has been adopted as the constitutive law of concrete. Sharma et al. (2005) observed that Legeron and Paultre (2003) model was the most suitable when compared with a large number of experimental results. The model is equally applicable for unconfined concrete. Rupture of confinement reinforcement is considered based on energy balance principle proposed by Mander (1984), in which stress-strain relationship of concrete is integrated numerically. The ultimate limit strain of concrete corresponds to the strain where energy absorbed by the confinement reinforcement is equal to the difference of the energy absorbed by the confined concrete and unconfined concrete. It is noted that, at the point of rupture of confinement reinforcement, longitudinal reinforcement is no more restrained and buckling of reinforcing bars occurs faster leading to collapse of the pier. 


\section{Constitutive law of reinforcing bars}

The nonlinear reinforcing bar model proposed by Gomes and Appleton (1997) has been chosen due to its simplicity and accuracy in predicting the sectional behaviour of piers. The model takes into account the effect of inelastic buckling of longitudinal reinforcing bars in a simplified way based on the plastic mechanism of buckled bar. It is noted that when a bar is subjected to cyclic load, its maximum strength is less than the maximum strength observed in monotonic tensile tests. Ultimate limit strain of the bar has been considered as 0.07 .

\section{(b) Modelling for sectional behaviour}

The sectional behaviour (moment-curvature response) of the columns are modelled in the computer program MNPhi (Paultre 2001) adopting the constitutive laws of concrete and reinforcing bars as discussed above. By assuming the strain profile, which complies with the assumption that plane sections remain plane, the stress in each layer and in the reinforcement is calculated. Based on the calculated axial force, the strain profile is then updated which converges with the applied axial force. The bending moment is calculated at that point.

c) Modelling for force-displacement behaviour

The displacement at the top of the pier which is fixed at the base is considered to be consisted of displacement due to bending (elastic and inelastic) along the length of the column, shear displacement along the length of the column, and displacement due to fix-end rotation for slip of the longitudinal reinforcement. Based on the flexibility approach, the displacement at the top of the pier is the sum of these three components (Park and Paulay 1976; Priestley et al. 2007):

$$
\Delta_{\text {top }}=\Delta_{\mathrm{b}}+\Delta_{\mathrm{s}}+\Delta_{\text {slip }}=\left(\Delta_{\mathrm{e}}+\Delta_{\mathrm{p}}\right)+\Delta_{\mathrm{s}}+\Delta_{\text {slip }}
$$

Where $\Delta_{\mathrm{e}}$ is the elastic displacement, $\Delta_{\mathrm{p}}$ is the plastic displacement, $\Delta_{\mathrm{S}}$ is the shear displacement, and $\Delta_{\text {slip }}$ is the slip displacement. Detailed description of the calculation procedure for $\Delta_{\mathrm{p}}, \Delta_{\mathrm{s}}$, and $\Delta_{\text {slip }}$ can be found in Priestley et al. (2007) and Sheikh and Legeron (2012). 
(d) Comparison with experimental investigations

The above modelling method for force-displacement response of bridge piers has been compared with the experimental investigations of 8 bridge piers in Lehman et al. (2004). The comparison between experimental results and analytical investigation has been shown in Figure 2. It can be observed that the analytical method predicts the experimental result with good accuracy. Also, performance points, or LS, have been well predicted. LS-1B (yield displacements) has been predicted very well with an average difference of less than 1\%. LS-2 (spalling of concrete cover) has been predicted with an average difference of only $10 \%$. It can be observed that the ratio of experimental/analytical result is comparatively high for Colum 828 for LS-2. LS-3 (core crushing/fracture of longitudinal bars/fracture of transverse hoops/buckling of longitudinal bars/ strength degradation) has also been predicted with an average difference of $10 \%$. It is noted that experimental investigations were performed based on nominal ductility and performance points were shown at the highest point of the displacement of the load cycle. Hence, even if the actual performance point falls within the range of two displacement cycles, it will only be reported as the displacement for the latter cycle of load application. Although the analytical method predicts the displacements of the bridge pier for buckling of reinforcing bars, bar fracture, hoop fracture and strength degradation, the experimental investigations in Lehman et al. (2004) reported the same displacements for reinforcing bar buckling and loss of strength, which is common in experimental investigations. Similar limitations for displacement cycles are also applicable at this stage of loadings. Nonetheless, the analytical method very well simulated the experimental observations. As the analytical method not only predicts the force displacement response but also predicts quite well the performance points, the modelling method has been applied for the performance evaluation of bridge piers design according to CHBDC in the following sections.

(e) Seismic performance of bridge piers

Seismic performance of bridge piers designed according to CHBDC has been evaluated in terms of acceleration (peak ground acceleration of the earthquake ground motion based on the code recommended response spectrum)-displacement (displacement of the bridge pier under respective 
earthquake ground motion) response, based on substitute structure approach (Shibata and Sozen 1976), using the force-displacement response computed above. The secant stiffness, $K_{\text {eq }}$, (Eq. [2]) and the effective period, $T_{\text {eff }}$ (Eq. [3]) of the bridge pier at every point on the force-displacement response have been calculated:

[2] $K_{e q}=\frac{F_{i}}{\Delta_{i}}$

where, $F_{i}$ and $\Delta_{i}$ are the force and displacement, respectively, at a point in the forcedisplacement diagram.

[3] $T_{\text {eff }}=2 \pi \sqrt{\frac{M_{s}}{K_{e q}}}$

Where, $M_{s}$ is the seismic mass of the pier, which includes tributary mass of the bridge superstructure plus $50 \%$ mass of the pier and pier cap.

Based on the ductility $(\mu)$ of the bridge piers at the level of displacement, the effective damping $\left(\zeta_{\text {eff }}\right)$ have also been calculated based on the recommendation in Kowalsky et al. (1995), considering idealized elasto-plastic response (Eq. [4]).

[4] $\zeta_{\text {eff }}=\zeta_{o}+\frac{1}{\pi}\left(1-\frac{1}{\sqrt{\mu}}\right)$

Where, $\zeta_{\mathrm{o}}$ is the damping before the yielding of the bridge pier, which is considered as 0.05 . The elastic seismic response coefficient $\left(\mathrm{C}_{\mathrm{sm}}\right)$ in the $\mathrm{CHBDC}$ is then modified by a damping correction factor, DMF, according to EC8 (2004) (Eq. [5]).

[5] $\mathrm{DMF}=\sqrt{\frac{7}{2+\zeta}}$ 
The force level (calculated from elastic seismic response coefficient, $C_{s m}$ ) at $T_{\text {eff }}$ in the damped response spectrum (after application of DMF) with $\mathrm{PGA}=1 \mathrm{~g}$ has been computed. The computed force level has been compared with the capacity of the bridge pier (i.e., force level corresponding to the displacement level in the force-displacement response) to calculate the PGA of earthquake events in which bridge pier will be subjected to the considered displacement level. The procedure for the calculation of PGA of the earthquake event has been carried out for all the points in the forcedisplacement response and represented as PGA-displacement response of the bridge pier (Figure 1). Performance points in terms of engineering parameters (Table 2) have been superimposed in the PGA-displacement response of the bridge pier (Figure 1). Such diagram clearly identifies the damage states (or performance points) and the corresponding earthquake ground motion in terms of PGA. The simplified method outlined herein has the ability to identify the seismic performance of bridge piers for a wide range of earthquake scenarios (PGA based on codified design response spectrum format). It is noted that the modelling method described above is to identify the local damage parameter (for bridge piers). However, such damage parameters may reasonably indicate the performance levels of typical bridges supported only by piers.

\section{PERFORMANCE OF BRIDGES DESIGNED ACCORDING TO CANADIAN HIGHWAY BRIDGE DESIGN CODE (CHBDC)}

The seismic design approach adopted in CHBDC code is force based, as discussed before, where strength is used as a measure of seismic performance. Four performance levels linked with different return period (RP) earthquake events have been specified in the commentary of CHBDC (Table 1). The seismic force reduction factors $(R)$ are 3 and 5, respectively, for single reinforced concrete pier and for multiple column pier bent. The higher $R$-factor for multicolumn pier bent is due to high degree of redundancy in a multicolumn bent and expected low likelihood of total collapse. However, such assumption for high $R$-factor for multi-column pier bent is counter-intuitive when the dominant response of the bridge is in the longitudinal direction. The importance factors (I-factor) are 3.0, 1.5 and 1.0 for lifeline bridges, emergency route bridges, and other bridges, respectively. $I$-factors for the three different bridge classes reflect their very different performance expectations (Table 1). 
Intuitively, the I-factor should be related to the seismic hazard for the region, as the specified performance objectives are related to the return RP of earthquake events.

This section endeavours to evaluate seismic performance of bridges designed according to CHBDC, using the modelling method outlined in the previous section, and identifies the limitations of the design rules in achieving the specified performance objectives. The bridges considered herein are supported by only piers, and hence seismic performances are solely dependent on the inelastic behaviour of the bridge piers. In such cases, the seismic performance of bridge piers may represent the seismic performance of the bridges.

Seismic performance of bridge piers is mainly related to their natural vibration period ( $\mathrm{T}$ ), aspect ratio ( $L / D$ ratio, where $L$ is the effective height of the pier and $D$ is the pier dimension), axial load level $\left(N=P / f^{\prime}{ }_{c} A_{g}\right.$, where $P$ is the axial load, $f{ }^{\prime}{ }_{c}$ is the characteristic strength of concrete and $A_{g}$ is the gross area of the pier cross-section), and longitudinal reinforcement ratio $\left(\rho_{g}\right)$. The effects of these parameters have been evaluated based on the analyses of 11 bridges in order to identify the influence of these parameters on the seismic performance objectives specified in CHBDC (Table 3).

The application of the developed seismic performance evaluation method has been demonstrated for a typical 3-span highway bridge (S12-LD5-T10-N10 in Table 3). The lengths of end spans and midspan are $28 \mathrm{~m}$ and $35 \mathrm{~m}$, respectively (Figure 3). The bridge is supported by two single piers with pier cap at the top. The height of the piers is 7.5 and the cross-sectional dimension (diameter) is $1500 \mathrm{~mm}$. The bridge pier has been designed according to the design rules in CHBDC. It is noted that CHBDC requires that the elastic seismic effect from the two principal directions should combined based on $30 \%$ combination rule (CSA 2006). Also, dead load factors for earthquake effect are 0.80 and 1.25, which are essentially axial load $(P)$ for the pier section considered herein. The seismic weight, $W_{s}$, is calculated by adding $50 \%$ of pier cap and column weight to seismic weight of the deck. The vibration period of the bridge is calculated based on the cracked sectional stiffness of the pier, where cracked stiffness is considered as $50 \%$ of the gross section stiffness. The vibration period of the typical bridge considered is $1.0 \mathrm{sec}$. (Table 3 ). The design strength of concrete is considered $40 \mathrm{MPa}$, which implies 
that minimum design longitudinal reinforcement for the piers should be $1.2 \%$. The transverse reinforcement ratios for the piers at the plastic hinge region and other regions have been calculated as $1.05 \%$ and $0.54 \%$, respectively. Based on an iterative procedure, such design corresponds to an $A I$ ( $A=$ design peak ground acceleration and $I=$ importance factor) value of $0.27 \mathrm{~g}$ (i.e., $P G A=0.27 \mathrm{~g}, 0.18$ $\mathrm{g}$ and $0.09 \mathrm{~g}$ for other, emergency-route and lifeline bridges, respectively) on a soil profile type II site (CSA 2006).

Force-displacement and PGA-displacement response of the typical bridge have been shown in Figures 4(a-b). The ratio of actual yield strength and design yield strength has been calculated as 1.14 , which is considered within the expected range. The performance of the bridge in different earthquake events can be evaluated once the PGA value of such earthquake event is known. The PGA values other than design earthquake event ( $\mathrm{RP}=475$ years) are sometimes expressed as ratios with the PGA of the design earthquake event, termed herein as normalized PGA. Currently in CHBDC, a large earthquake event is considered as $\mathrm{RP}=1000$ year earthquake event. There appears to be an agreement, however, among the earthquake engineering community to consider large earthquake events as $\mathrm{RP}=2500$ year earthquake event or even $\mathrm{RP}=10,000$ year earthquake event (Tsang 2011; Chandler et al. 2002). It is noted that the public review version of CAN/CSA-S6-14 (CSA 2013) specifies performance levels for earthquakes of $2 \%$ probability of exceedance in 50 years $(\mathrm{RP}=2475$ years $)$. Hence, this paper also evaluates the performance of bridges for large earthquake events with $\mathrm{RP}=2500$ years. It has been observed by the authors, based on the calculations for some places in Canada, that normalized PGAs for $\mathrm{RP}=1000$ year earthquake event for the east coast and for the Cascadian zone in the west coast of Canada are 1.60 and 1.35, respectively (Table 4). Normalized PGAs for $\mathrm{RP}=2500$ year events are 2.70 and 1.85 , respectively, and for $\mathrm{RP}=100$ year earthquake events are 0.35 and 0.50 , respectively, for the east coast and for the Cascadian zone in the west coast of Canada (Table 4). These ratios are similar to the ratios calculated by Adams et al. (1999).

In order to identify the performance of the bridge in different RP earthquake events, the response of the bridge (S12-LD5-T10-N10) in terms of normalized PGA has been shown in Figure 4(c-e). The normalized PGAs for no damage, minor damage, moderate damage, repairable damage, and 
reconstructions are $0.064,0.38,0.81,1.49$, and 1.66 , respectively, for other bridges. It can be observed that current design does not comply with the requirement of all traffic immediate use for other bridges under small to moderate earthquake event $(\mathrm{RP}=100$ years $)$ when located in the west coast of Canada. If the inherent conservatism of the design (actual yield strength/design yield strength $=1.14$ ) is not considered, the bridge does not comply with the same requirement when located in the east coast of Canada. The bridge also does not comply with the requirement of no collapse performance level for large earthquake event (considering large earthquake event as $\mathrm{RP}=2500$ year earthquake event) when located in both the east and the west coast of Canada (Figure 4c). If the inherent conservatism of the design is not considered, the bridge does not even comply with the same requirement in $\mathrm{RP}=1000$ year earthquake event when located in the east coast of Canada

The normalized PGAs for no damage, minor damage, moderate damage, repairable damage, and reconstructions are $0.096,0.57,1.22,2.23$, and 2.50 , respectively, for emergency-route bridges. The bridge does not comply with the requirement of repairable damage in large earthquake event $(\mathrm{RP}=$ 2500 years) when located in the east coast of Canada. However, such requirement is met when large earthquake event is considered as $\mathrm{RP}=1000$ year earthquake event.

The normalized PGAs for no damage, minor damage, moderate damage, repairable and reconstructions are $0.19,1.14,2.44,4.46$, and 4.99 , respectively, for lifeline bridges. It can be observed that bridge does not comply with the requirement of emergency vehicle immediate use in large earthquake events $(\mathrm{RP}=2500$ years $)$ when located in the east coast of Canada. However, it complies with the same requirement when the large earthquake event is considered as $\mathrm{RP}=1000$ year earthquake event.

For direct comparison, Damage Response Factor (DRF) has been introduced herein. DRF can be defined as the ratio of PGA between the LS under consideration with the PGA at LS-1B. It is noted that up to LS-1B, the response of the bridge is essentially elastic. The DRFs have been calculated as 1 , 2.1, 3.9 and 4.4 for minor damage, moderate damage, repairable damage and reconstruction, respectively, for S12-LD5-T10-N10 (Figure 4c). The DRF is mainly dependent on the design rules in 
CHBDC. Hence, the DRF is independent of the importance level of the bridge (Figures 4c-e). It is noted that DRF represents the capacity of the bridge and hence the higher the DRF the better the performance of the bridge is. For the assessment of seismic performance of the bridge designed according to CHBDC, $R / I$ value recommended in the code should be compared with the DRF/ normalized PGA. For a performance requirement in a given return period earthquake event, R/I value larger than DRF/normalised PGA represents noncompliance between design rules and specified seismic performance objective In other words, $(R / I) \times$ (normalized PGA/DRF) value greater than 1 represents noncompliance between design rules and specified seismic performance requirements. Table 5 compares the actual seismic performance of the bridge with the specified seismic performance in terms of $(R / I) \times$ (normalized PGA/DRF) for S12-LD5-T10-N10. It is noted that in Table 5, the ratio of actual yield strength/design yield strength has not been considered.

The typical bridge has been modified to investigate the effect of natural vibration period (T), aspect ratio $(L / D)$, axial load level $(N)$, and longitudinal reinforcement ratio $\left(\rho_{g}\right)$. Also, two bridges with multicolumn pier bent have been designed in order to investigate the validity of higher $R$-factor for the pier bent. It is noted that $I$-factor for these bridges is considered as 1.0 (other bridges). It can be observed from last three columns of Table 3 that period of vibration has insignificant effect on the seismic behaviour of bridges (S12-LD5-T05-N10, S12-LD5-T10-N10 and S12-LD5-T20-N10 in Table 3). The DRF of bridge slightly increases with the increase in the vibration period; however, such difference is within $5 \%$ of the DRF for typical bridge considered herein for all damage levels. The aspect ratio of bridge pier has significant influence in the seismic capacity of the bridge (S12LD3-T10-N10, S12-LD5-T10-N10, and S12-LD8-T10-N10 in Table 3). It can be seen that the DRF decreases with the increasing aspect ratio of the piers indicating a reduction in the seismic performance under different RP earthquake events. The DRF for reconstruction becomes double when the aspect ratio of the bridge pier varies from 3 to 8 . This is mainly due to secondary P- $\Delta$ effect for larger aspect ratio of bridge piers. It is noted that AASHTO (2007) imposes restriction on P- $\Delta$ effect to reduce large ductility demand on the plastic hinges of bridge piers, large residual deformation and possibly collapse. Similar requirements can also be considered in CHBDC. 
Axial load level of the piers has significant influence on the seismic capacity of the bridge (S12-LD5T05-N05, S12-LD5-T05-N10, and S12-LD5-T05-N20 in Table 3). The performance of the bridge is better for lower axial load levels. Kowalsky (2000) also presented similar findings. The average DRF for all damage states for bridge piers with $N=0.05$ is 1.7 times of that for bridge piers with $N=0.2$. It can also be observed that higher longitudinal reinforcement ratio yields higher DRF indicating that the seismic performance of bridge improves with the increase in the longitudinal reinforcement in the bridge pier (S12-LD5-T05-N10, S25-LD5-T05-N10, and S50-LD5-T05-N10 in Table 3). However, such increase is within $20 \%$ for longitudinal reinforcement ratio between $1.2 \%$ and $5 \%$. This can be seen as in contradiction with ductility based design where designer assumes that longitudinal reinforcement reduces ductility capacity, as the yield displacement increases with the increase in the amount of longitudinal reinforcement. It is demonstrated here that design based solely on ductility is not entirely compliant with performance based design. It should be noted that lower longitudinal reinforcement ratio will require higher pier cross-section and will have lower $\mathrm{P}-\Delta$ effect and lower axial load level. Hence, proper cost analyses need to be carried out before the design decision is made.

The typical bridge considered has been further modified to investigate the seismic performance of bridges with multi-column pier bents. Two bridges with two-column pier bent having longitudinal and transverse vibration periods $1.4 \mathrm{~s}$ and $0.4 \mathrm{~s}$ (period ratio, $\mathrm{TR}=3.5$ ), and $0.5 \mathrm{~s}$ and $0.5 \mathrm{~s}$ (period ratio $\mathrm{TR}=1.0$ ) have been designed (B12-LD5-TR35-N05 and B12-LD5-T10-N05 in Table 3). The axial load level $(N)$ of the piers has been considered as 0.05 . It should be noted that seismic weights of the bridge piers have been adjusted to consider the variation of vibration period in both longitudinal and transverse direction. It can be observed that the DRF of the two bridges are very similar indicating that TR does not have significant influence on the seismic behaviour of the bridge. The bridge has been observed to perform better (higher DRF) in the transverse direction which might be attributed to the fame action in the transverse direction. As indicated before, the design of the bridges with two columns pier bents are governed by the earthquake ground motion in the longitudinal direction. The most important observation is that the DRFs in the longitudinal direction are very similar to the bridge with single pier at the same axial load level. Hence, the adoption of higher $R$-factor for the pier bent in 
the design code is non-conservative, especially for bridges dominated by the response in the longitudinal direction. The results presented above indicate that the design rules adopted in CHBDC may yield highly variable levels of damage under design earthquake scenarios.

\section{IMPLICIT DESIGN RULES FOR PERFORMANCE BASED DESIGN OF BRIDGES}

Recent research efforts in the seismic design of bridges are moving away from traditional single limit state design technique. Multiple performance objectives, each paring with seismic hazard level, require more complex design framework. The design framework should enable design and acceptance criteria to be specified by a continuum of limit states and should incorporate uncertainty in all the sources of data (both input and output) (Mackie and Stojadinovic 2007). A large number of analyses are required to develop such performance based seismic design framework. However, it should always be preferable for seismic design codes to adopt simplified design guideline, as complex analysis techniques, training and resources may not be always available in the design firms, specifically for routine design projects. In the light of limited analyses performed in this paper it is may be possible to outline design guidelines in term of Performance Response Modification Factor (PRMF) to meet the seismic performance levels specified in CHBDC. PRMF has been calculated as the ratio of required DRF for specified performance objective (Table 1) in the earthquake event considered with the normalized PGA of the earthquake event. For example, in the case of other bridge, the performance requirement in design earthquake event $(\mathrm{RP}=475$ years) is repairable damage. For the typical bridge considered herein, the DRF value for the repairable damage is 3.9 (Figure 4c). For the east and the west coast of Canada, the normalized PGA for $\mathrm{RP}=475$ year event is 1.0. Hence, the PRMF for typical "other" bridge in both east coast and west coast of Canada is $3.9 / 1=$ 3.9. It is noted that PRMF is dependent on the seismicity of the area, as it is a ratio of DRF and normalized PGA. In Table 6 implicit PRMF factors have been presented for the typical bridge for all performance levels together with the normalized PGA for different RP earthquake events. To satisfy all the performance levels for different RP earthquake events, the simplest way is to adopt the 
minimum PRMF for the bridge type under consideration. For example, for the typical lifeline bridge considered herein, the design PRMFs are 0.78 and 1.00, respectively, for bridges located in the east coast and the west coast of Canada, when large event is considered as $\mathrm{RP}=2500$ year earthquake event. In such cases, all the performance requirements in different RP earthquake events will be automatically satisfied.

It should be noted that CHBDC requires that important bridges should be designed for seismic coefficients equal to that of ordinary bridges multiplied by $I$-factors. In the proposed implicit design rules, importance levels of the bridge have already been considered in the PRMF and there is no requirement for any arbitrary $I$-factor. In this approach, the performance is matched directly with the seismic input corresponding to different RP earthquake events. It is also noted that AASHTO (2007) proposed $R$-factors inherently consider the importance level of the bridge, as in the case for PRMF. From the Table 6, it can be observed that the design is dictated by large earthquake event in the east coast of Canada when the large earthquake event is considered as $\mathrm{RP}=2500$ year earthquake event. However, if the large earthquake is considered as $\mathrm{RP}=1000$ year earthquake event, the design is dictated by $\mathrm{RP}=475$ year earthquake event for lifeline and emergency-route bridges and $\mathrm{RP}=1000$ year earthquake event for other bridges in the east coast of Canada. In the west coast of Canada, the design is dictated by $\mathrm{RP}=100$ year earthquake event for emergency-route and other bridges and $\mathrm{RP}=$ 475 year earthquake event for lifeline bridges.

The implicit design rule presented herein clearly indicates the importance of the inclusion of seismicity of the area in the design and is supported by recent research investigations on performance based seismic design and assessment of bridges. Such implicit design rules can also be obtained for other bridges designed and analysed in this paper based on the DRFs in Table 3. However, the implicit design rule presented herein should be validated with rigorous nonlinear time history analyses before its inclusion in the design codes. 


\section{CONCLUSIONS}

A set of performance objectives has been specified in the commentary of Canadian Highway Bridge Design Code, CHBDC (CSA 2006). However, there is no requirement in the code to check the attainment of such multiple performance objectives for the designed bridges. Moreover, the specified performance objectives are very descriptive and are not linked with any engineering parameter. This paper correlates seismic performance objectives (qualitative and quantitative) with engineering parameters that are developed based on the data from experimental investigations and field investigations reports of recent earthquakes.

A simplified checking method has been outlined which is developed based on equivalent static (pushover) analyses procedures incorporating substitute structure approach. The method has been fully validated with available experimental data. The developed method not only replicates forcedisplacement behaviour of the bridge piers but also replicates the performance points (engineering parameters) with reasonable accuracy.

It has been found that design rules in the CHBDC do not automatically satisfy the specified multiple seismic performance objectives. Moreover, such performance objectives are dependent on the seismicity of the area (east coast and the Cascadian zone in the west coast of Canada) which have not been addressed in the code. In addition, the higher force reduction factor $(R)$ suggested in the code for bridges supported by multi-column pier bents is non-conservative when the performance of the bridge is dominated by the earthquake ground motion in the longitudinal direction. It has also been found that the design rules adopted in CHBDC may yield highly variable levels of damage in an earthquake event.

This paper presents the seismic performances of bridges in terms of damage response factor (DRF) for the 11 bridges designed according to CHBDC. Implicit seismic design rule for a typical bridge have been outlined based on the damage state (or damage response factor, DRF) and the seismicity of the area. Such implicit seismic design rule may have the potential for further development with a view to incorporating in the future seismic design codes. 


\section{REFERENCES}

AASHTO. 2007. LRFD Bridge Design Specifications. American Association of State Highway and Transportation Officials, Washington, D.C., USA.

Adams, J., Weichert, D., and Halchuk, S. 1999. Lowering the Probability Level - Fourth Generation Seismic Hazard Results for Canada at the 2\% in 50 Year Probability Level. In proceedings of the 8th Canadian conference on Earthquake Engineering, Vancouver, Canada. pp. 83-88.

AS 5100-2004. Australian Standards- Bridge Design. Standard Australia International Ltd. Sydney, NSW, Australia.

Basöz, N.I., Kiremidjian, A.S., and King, S.A. 1999. Statistical Analysis of Bridge Damage Data from the 1994 Northridge, CA, Earthquake. Earthquake Spectra, 15: 25-54.

Berry, M., Parrish, M., and Eberhard, M. 2004. PEER Structural Performance Database User's Manual. Pacific Earthquake Engineering Research Center, Univ. of California, Berkeley.

CSA. 2006. CAN/CSA-S6-06. Canadian Highway Bridge Design Code. CSA International, Ontario, Canada.

CSA. 2013. CAN/CSA-S6-14. Canadian Highway Bridge Design Code (Public Review Version). CSA International, Ontario, Canada.

Chandler, A.M., Lam, N.T.K., and Sheikh, M.N. 2012. Response Spectrum Predictions for Potential Near-Field and Far-Field Earthquakes Affecting Hong Kong: Soil Sites. Soil Dynamics and Earthquake Engineering, 22: 419-440.

Eurocode 8 (EC8). 2004. Design Provisions for Earthquake Resistance of Structures, Part 1- General Rules, Seismic Actions and Rules for Buildings, and Part 2-Bridges (European Prestandard). Brussels, Belgium.

Floren, A., and Mohammadi, J. 2001. Performance-Based Design Approach in Seismic Analysis of Bridges. Journal of Bridge Engineering, 6(1): 37-45. 
Gomes, A., and Appleton, J. 1997. Nonlinear Cyclic Stress-Strain Relationship of Reinforcing Bars Including Buckling. Engineering Structures, 19(10): 822- 826.

Hose, Y., Silva, P., and Seible, F. 2000. Development of a Performance Evaluation Database for Concrete Bridge Components and Systems under Simulated Seismic Loads. Earthquake Spectra, 16(2): 413-422.

Hsu, Y.T., and Fu, CC. 2004. Seismic Effect on Highway Bridges in Chi Chi Earthquake. Journal of Performance of Constructed Facilities, 18 (1): 47-53.

Kawashima, K., and Unjoh, S. 1997. The Damage of Highway Bridges in the 1995 Hyogo-Ken Nanbu Earthquake and its Impact on Japanese Seismic Design. Journal of Earthquake Engineering, 1(3): 505-543.

Kowalsky, M.J., Priestley, M.J.N., and Macrae, G.A. 1995. Displacement-Based Design of RC Bridge Columns in Seismic Regions. Earthquake Engineering and Structural Dynamics, 24(12): 1623-1643.

Kowalsky, M.J. 2000. Deformation Limit States for Circular Reinforced Concrete Bridge Columns. Journal of Structural Engineering, 126(8): 869-878.

Legeron, F., and Paultre, P. 2003. Uniaxial Confinement Model for Normal- and High-Strength Concrete Columns. Journal of Structural Engineering, 129(2): 241-252.

Lehman, D., Moehle, J., Mahin, S., Calderone, A., and Henry L. 2004. Experimental Evaluation of the Seismic Performance of Reinforced Concrete Bridge Columns. Journal of Structural Engineering, 130(6): 869-879.

Mackie, K.R., Stojadinovic, B. 2007. Performance-Based Seismic Bridge Design for Damage and Loss Limit States. Earthquake Engineering and Structural Dynamics, 36:1953-1971

Mander, J. B., Priestley, M.J.N., and Park, R. 1984. Seismic Design of Bridge Piers. Rep. No. 84-2, Univ. of Canterbury, Christchurch, New Zealand. 
Paultre, P. 2001. MNPHI: User manual. CRGP Rep. No. 2001-01, Department of Civil Engineering, University of Sherbrooke, Sherbrooke, Canada.

Priestley, M.J.N., Calvi, G.M., and Kowalsky, M.J. 2007. Displacement-Based Seismic Design of Structures. IUSS Press, Pavia, 721pp.

Saiidi, M. 2011. Managing Seismic Performance of Highway Bridges- Evolution in Experimental Research. Structure and Infrastructure Engineering, 7(7-8): 569-586.

Sharma, U., Bhargava, P. and Kaushik, K. 2005. Comparative Study of Confinement Models for High-Strength Concrete Columns. Magazine of Concrete Research, 57(4): 185-197.

Sheikh, M.N., Tsang, H.H., McCarthy, T.J., and Lam, N.T.K. 2010. Yield Curvature for Seismic Design of Circular Reinforced Concrete Columns. Magazine of Concrete Research, 62(10): 741-748.

Sheikh, M.N. and Legeron, F. 2012. Seismic Performance of Bridges Designed According to Contemporary Code Provisions. Joint research report- University of Wollongong, Australia, and University of Sherbrooke, Canada. 112 pp.

Shibata, A., and Sozen M.A. 1976. Substitute-Structure Method for Seismic Design in R/C. Journal of the Structural Division, ASCE, 102(1): 1-18

Tsang, H.H. 2011. Should We Design Buildings for Lower-Probability Earthquake Motion? Natural Hazards, 58:853-857 
Table 1. Performance requirements in CHBDC (CAN/CSA-S6-06)

\begin{tabular}{llll}
\hline Return period & \multicolumn{3}{c}{ Bridge } \\
\cline { 2 - 4 } & Lifeline & Emergency-route & Other \\
\hline $\begin{array}{l}\text { Small to moderate } \\
\text { earthquake }\end{array}$ & $\begin{array}{l}\text { All traffic } \\
\text { Immediate use }\end{array}$ & $\begin{array}{l}\text { All traffic } \\
\text { Immediate use }\end{array}$ & $\begin{array}{l}\text { All traffic } \\
\text { Immediate use }\end{array}$ \\
$\begin{array}{l}\text { Design earthquake } \\
\text { (475-year return period) }\end{array}$ & $\begin{array}{l}\text { All traffic } \\
\text { Immediate use }\end{array}$ & $\begin{array}{l}\text { Emergency vehicles } \\
\text { Immediate use }\end{array}$ & $\begin{array}{l}\text { Repairable } \\
\text { damage }\end{array}$ \\
$\begin{array}{l}\text { Large earthquake } \\
(1000 \text {-year return period) }\end{array}$ & $\begin{array}{l}\text { Emergency vehicles } \\
\text { Immediate use }\end{array}$ & Repairable damage & No collapse \\
\hline
\end{tabular}

Table 2. Qualitative and quantitative performance levels correlated with engineering parameters and repair techniques

\begin{tabular}{|c|c|c|c|c|c|}
\hline $\begin{array}{c}\text { Limit } \\
\text { states } \\
\text { (LS) }\end{array}$ & $\begin{array}{l}\text { Operational } \\
\text { performance } \\
\text { level }\end{array}$ & $\begin{array}{l}\text { Post } \\
\text { earthquake } \\
\text { serviceability }\end{array}$ & $\begin{array}{l}\text { Qualitative } \\
\text { performance } \\
\text { description }\end{array}$ & $\begin{array}{l}\text { Quantitative } \\
\text { performance } \\
\text { description }\end{array}$ & Repair \\
\hline $1 \mathrm{~A}$ & & & No cracks & $\sigma_{\mathrm{c}}=\mathrm{f}_{\mathrm{cr}}=0.4 \sqrt{ } \mathrm{f}_{\mathrm{c}}^{\prime}$ & No repair \\
\hline 1B & $\begin{array}{l}\text { Fully } \\
\text { Operational }\end{array}$ & Full service & $\begin{array}{l}\text { Few cracks that can be } \\
\text { easily repaired with no } \\
\text { consequence on } \\
\text { serviceability }\end{array}$ & $\sigma_{\mathrm{s}}=\mathrm{f}_{\mathrm{sy}}$ & $\begin{array}{l}\text { Limited epoxy } \\
\text { injection }\end{array}$ \\
\hline \multirow[t]{2}{*}{2} & $\begin{array}{l}\text { Delayed } \\
\text { Operational }\end{array}$ & $\begin{array}{l}\text { Limited } \\
\text { service } \\
\text { (emergency } \\
\text { vehicle only) }\end{array}$ & $\begin{array}{l}\text { Initiation of inelastic } \\
\text { deformation; onset of } \\
\text { concrete spalling; } \\
\text { development of } \\
\text { longitudinal cracks }\end{array}$ & $\begin{array}{l}\epsilon_{\mathrm{c}}=-0.004 \\
\epsilon_{\mathrm{s}}=0.007 \\
\text { crack width }=2 \\
\mathrm{~mm}\end{array}$ & $\begin{array}{l}\text { Epoxy } \\
\text { injection; } \\
\text { concrete } \\
\text { patching }\end{array}$ \\
\hline & & & $\begin{array}{l}\text { Wide crack width/ } \\
\text { spalling over full local }\end{array}$ & $\begin{array}{l}\epsilon_{\mathrm{c}=} \epsilon_{\mathrm{cc} 50} \text { (initial } \\
\text { core crushing) }\end{array}$ & $\begin{array}{l}\text { Extensive } \\
\text { repair / }\end{array}$ \\
\hline
\end{tabular}


Stability Closed

mechanism regions;

buckling of main

reinforcement; fracture

of transverse hoops;

crushing of core

concrete; strength

degradation $\epsilon_{\mathrm{c}}=\epsilon_{\mathrm{cu}}$ (fracture of reconstruction

hoops)

$\epsilon_{\mathrm{s}}=\epsilon_{\mathrm{su}}=0.07$

(longitudinal

reinforcement

fracture)

$\epsilon_{\mathrm{s}}=\epsilon_{\text {scr }}$ (onset of

buckling)

$\mathrm{f}^{\prime}{ }_{\mathrm{c}}=$ axial strain of concrete; $\varepsilon_{\mathrm{cc} 50}=$ post peak axial strain in concrete when capacity drops to $50 \%$ of confined strength; $\varepsilon_{\mathrm{cu}}=$ ultimate strain of concrete; $\varepsilon_{\mathrm{s}}=$ average tensile strain in longitudinal reinforcement, $\varepsilon_{\mathrm{su}}=$ tensile strain at fracture; $\epsilon_{\mathrm{scr}}=$ steel strain at the onset of buckling of longitudinal bars 
Table 3. Case study bridges

\begin{tabular}{|c|c|c|c|c|c|c|c|c|c|c|c|}
\hline Case Number & \multicolumn{8}{|c|}{ Properties of the case study bridges } & \multicolumn{3}{|c|}{ Damage Response Factor (DRF) } \\
\hline S12-LD5-T10-N10 & \multicolumn{2}{|l|}{ Single } & 1.2 & 5 & 1.0 & 1.5 & 0.1 & 6000 & 2.1 & 3.9 & 4.4 \\
\hline S12-LD5-T05-N10 & \multicolumn{2}{|l|}{ Single } & 1.2 & 5 & 0.5 & 1.0 & 0.1 & 1000 & 2.2 & 3.8 & 4.2 \\
\hline S12-LD3-T10-N10 & \multicolumn{2}{|l|}{ Single } & 1.2 & 3 & 1.0 & 2.0 & 0.1 & 37000 & 2.4 & 4.7 & 5.8 \\
\hline S12-LD8-T10-N10 & \multicolumn{2}{|l|}{ Single } & 1.2 & 8 & 1.0 & 1.0 & 0.1 & 500 & 2.0 & 2.7 & 2.9 \\
\hline S12-LD5-T10-N05 & \multicolumn{2}{|l|}{ Single } & 1.2 & 5 & 1.0 & 1.5 & 0.05 & 6000 & 2.3 & 4.8 & 5.8 \\
\hline \multirow[t]{2}{*}{ B12-LD5-TR35-N05 } & \multirow[t]{2}{*}{ pier bent } & Long & 1.2 & 5 & 1.4 & 1.0 & 0.05 & 16000 & 2.3 & 4.8 & 5.7 \\
\hline & & Trans & & & 0.4 & & & 8000 & 2.7 & 6.0 & 7.6 \\
\hline \multirow[t]{2}{*}{ B12-LD5-T10-N05 } & \multirow[t]{2}{*}{ pier bent } & Long & 1.2 & 5 & 0.5 & 1.0 & 0.05 & 2000 & 2.3 & 5.0 & 5.9 \\
\hline & & Trans & & & 0.5 & & & 12500 & 2.7 & 6.0 & 7.6 \\
\hline
\end{tabular}

Note: Bold fonts represent properties and DRFs of the typical bridge considered in the paper 
Table 4. Ratio of PGA for different return period (RP) earthquake events

\begin{tabular}{|c|c|c|c|c|c|c|c|}
\hline Canadian Cities & $\begin{array}{l}\text { PGA for Small } \\
\text { to moderate } \\
\text { earthquakes } \\
\mathrm{RP}=100 \text { years }\end{array}$ & $\begin{array}{l}\text { PGA for } \\
\text { Design } \\
\text { earthquakes } \\
\mathrm{RP}=475 \text { years } \\
\end{array}$ & $\begin{array}{l}\text { PGA for Large } \\
\text { earthquakes } \\
\mathrm{RP}=1000 \text { years }\end{array}$ & $\begin{array}{l}\text { PGA for Large } \\
\text { earthquakes } \\
\mathrm{RP}=2500 \text { years }\end{array}$ & $\begin{array}{l}\text { Ratio of PGA } \\
\text { between } \mathrm{RP}=100 \\
\text { years and } \mathrm{RP}=475 \\
\text { years }\end{array}$ & $\begin{array}{l}\text { Ratio of PGA } \\
\text { between } R P= \\
1000 \text { years and } \\
R P=475 \text { years }\end{array}$ & $\begin{array}{l}\text { Ratio of PGA } \\
\text { between } \mathrm{RP}= \\
2500 \text { years and } \\
\mathrm{RP}=475 \text { years }\end{array}$ \\
\hline \multicolumn{8}{|c|}{ East Coast of Canada } \\
\hline Montreal & 0.039 & 0.124 & 0.201 & 0.327 & 0.31 & 1.62 & 2.64 \\
\hline Quebec & 0.033 & 0.101 & 0.165 & 0.0285 & 0.33 & 1.63 & 2.82 \\
\hline Ottawa & 0.039 & 0.122 & 0.201 & 0.324 & 0.32 & 1.65 & 2.66 \\
\hline Sherbrooke & 0.022 & 0.057 & 0.085 & 0.135 & 0.39 & 1.49 & 2.37 \\
\hline Riviere du loup & 0.076 & 0.213 & 0.316 & 0.483 & 0.36 & 1.48 & 2.27 \\
\hline Rimouski & 0.028 & 0.077 & 0.122 & 0.195 & 0.36 & 1.58 & 2.53 \\
\hline Tadousac & 0.05 & 0.136 & 0.212 & 0.337 & 0.37 & 1.56 & 2.48 \\
\hline Charlottetown & 0.007 & 0.09 & 0.028 & 0.49 & 0.37 & 1.47 & 2.58 \\
\hline Fredericton & 0.018 & 0.055 & 0.098 & 0.182 & 0.33 & 1.78 & 3.31 \\
\hline Halifax & 0.013 & 0.036 & 0.055 & 0.086 & 0.36 & 1.53 & 2.39 \\
\hline Iqualuit & 0.006 & 0.015 & 0.022 & 0.036 & 0.40 & 1.47 & 2.40 \\
\hline Regina & 0.003 & 0.014 & 0.023 & 0.04 & 0.21 & 1.64 & 2.86 \\
\hline Toronto & 0.01 & 0.04 & 0.068 & 0.12 & 0.25 & 1.70 & 3.00 \\
\hline Winnipeg & 0.003 & 0.011 & 0.019 & 0.036 & 0.27 & 1.73 & 3.27 \\
\hline \multicolumn{5}{|c|}{ Considered Average ratio } & 0.35 & $\mathbf{1 . 6 0}$ & 2.70 \\
\hline \multicolumn{8}{|c|}{ West Coast of Canada } \\
\hline Vancouver & 0.118 & 0.251 & 0.339 & 0.471 & 0.47 & 1.35 & 1.88 \\
\hline Whitehorse & 0.035 & 0.065 & 0.084 & 0.115 & 0.54 & 1.29 & 1.77 \\
\hline Victoria & 0.166 & 0.339 & 0.45 & 0.612 & 0.49 & 1.33 & 1.81 \\
\hline Richmond & 0.124 & 0.268 & 0.362 & 0.501 & 0.46 & 1.35 & 1.87 \\
\hline \multicolumn{5}{|c|}{ Considered Average ratio } & 0.50 & 1.35 & 1.85 \\
\hline
\end{tabular}


Table 5. Actual seismic performance versus stipulated seismic performance for the typical bridge designed according to CHBDC

\begin{tabular}{|c|c|c|c|c|c|c|c|c|c|c|c|}
\hline \multirow[t]{4}{*}{ Return Period } & \multicolumn{2}{|c|}{ Normalized PGA } & \multirow{2}{*}{\multicolumn{3}{|c|}{ Damage response factor (DRF) }} & \multicolumn{6}{|c|}{$(R / I)_{\text {design }} \times(\text { normalized PGA/DRF) })_{\text {performance }}$} \\
\hline & \multirow[b]{2}{*}{ East coast } & \multirow[b]{2}{*}{$\begin{array}{l}\text { West } \\
\text { Coast }\end{array}$} & & & & \multicolumn{3}{|c|}{ Bridges in East Coast of Canada } & \multicolumn{3}{|c|}{ Bridges in west coast of Canada } \\
\hline & & & Line-line & $\begin{array}{l}\text { Emergency- } \\
\text { route }\end{array}$ & \multirow[t]{2}{*}{ Other } & Lifeline & $\begin{array}{l}\text { Emergency- } \\
\text { route }\end{array}$ & Other & Lifeline & $\begin{array}{l}\text { Emergency- } \\
\text { route }\end{array}$ & Other \\
\hline & & & & & & $R / I=1.0$ & $R / I=2.0$ & $R / I=3.0$ & $R / I=1.0$ & $R / I=2.0$ & $R / I=3.0$ \\
\hline $\begin{array}{l}\text { Small to moderate } \\
\text { earthquake }(\mathrm{RP}=100 \text { years })\end{array}$ & 0.35 & 0.50 & 1 & 1 & 1 & 0.35 & 0.70 & 1.05 & 0.50 & 1.00 & 1.50 \\
\hline $\begin{array}{l}\text { Design earthquake } \\
\text { ( } \mathrm{RP}=475 \text { years) }\end{array}$ & 1 & 1 & 1 & 2.1 & 3.9 & 1.00 & 0.95 & 0.77 & 1.00 & 0.95 & 0.77 \\
\hline $\begin{array}{l}\text { Large earthquake } \\
(\mathrm{RP}=1000 \text { years })\end{array}$ & 1.6 & 1.35 & 2.1 & 3.9 & 4.4 & 0.76 & 0.82 & 1.09 & 0.64 & 0.69 & 0.92 \\
\hline $\begin{array}{l}\text { Large earthquake } \\
(\mathrm{RP}=2500 \text { years })\end{array}$ & 2.7 & 1.85 & 2.1 & 3.9 & 4.4 & 1.29 & 1.38 & 1.84 & 0.88 & 0.95 & 1.26 \\
\hline
\end{tabular}

Note: Bold fonts represent noncompliance between the design rules and the specified seismic performance objectives in CHBDC 
Table 6. Implicit seismic design rules for the typical bridge

\begin{tabular}{|c|c|c|c|c|c|c|c|c|c|c|c|}
\hline \multirow[t]{3}{*}{ Earthquake Events } & \multicolumn{2}{|c|}{$\begin{array}{l}\text { Normalized } \\
\text { PGA }\end{array}$} & \multicolumn{3}{|c|}{ Damage response factor (DRF) } & \multicolumn{6}{|c|}{ Performance Response Modification Factor (PRMF) } \\
\hline & \multirow{2}{*}{$\begin{array}{l}\text { East } \\
\text { coast }\end{array}$} & \multirow{2}{*}{$\begin{array}{l}\text { West } \\
\text { Coast }\end{array}$} & & & & \multicolumn{3}{|c|}{ Bridges in East Coast of Canada } & \multicolumn{3}{|c|}{ Bridges in West Coast of Canada } \\
\hline & & & Lifeline & $\begin{array}{l}\text { Emergency- } \\
\text { route }\end{array}$ & Other & Lifeline & $\begin{array}{l}\text { Emergency- } \\
\text { route }\end{array}$ & Other & Lifeline & $\begin{array}{l}\text { Emergency- } \\
\text { route }\end{array}$ & Other \\
\hline $\begin{array}{l}\text { Small to moderate } \\
\text { earthquake }(\mathrm{RP}=100 \\
\text { years) }\end{array}$ & 0.35 & 0.50 & 1 & 1 & 1 & 2.86 & 2.86 & 2.86 & 2.00 & 2.00 & 2.00 \\
\hline $\begin{array}{l}\text { Small to moderate } \\
\text { earthquake }(\mathrm{RP}=475 \\
\text { years) }\end{array}$ & 1 & 1 & 1 & 2.1 & 3.9 & 1.00 & 2.10 & 3.90 & 1.00 & 2.10 & 3.90 \\
\hline $\begin{array}{l}\text { Large earthquake } \\
(\mathrm{RP}=1000 \text { years })\end{array}$ & 1.6 & 1.35 & 2.1 & 3.9 & 4.4 & 1.31 & 2.44 & 2.75 & 1.56 & 2.89 & 3.26 \\
\hline $\begin{array}{l}\text { Large earthquake } \\
(\mathrm{RP}=2500 \text { years })\end{array}$ & 2.7 & 1.85 & 2.1 & 3.9 & 4.4 & 0.78 & 1.44 & 1.63 & 1.14 & 2.11 & 2.38 \\
\hline
\end{tabular}

Note: Bold fonts represent controlling PRMF 


\section{FIGURE CAPTIONS}

Figure 1. Post-earthquake serviceability and performance limit states

Figure 2. Comparison between experimental results and analytical investigation

Figure 3. Typical 4-span Highway Bridge

Figure 4. Seismic performance of a typical bridge (S12-LD5-T10-N10 in Table 3) designed according to CHBDC 


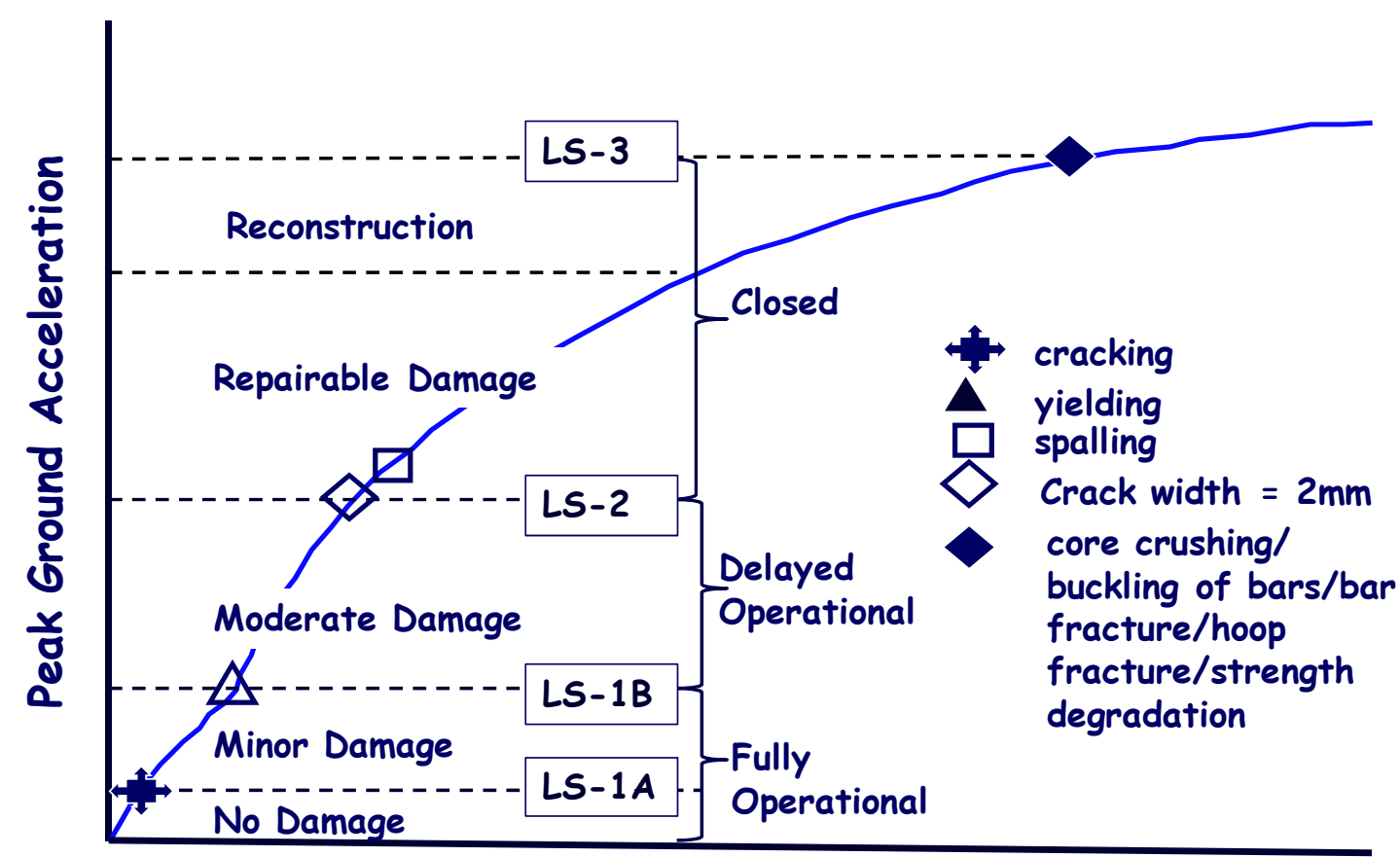

Displacement

Figure 1. Post-earthquake serviceability and performance limit states 


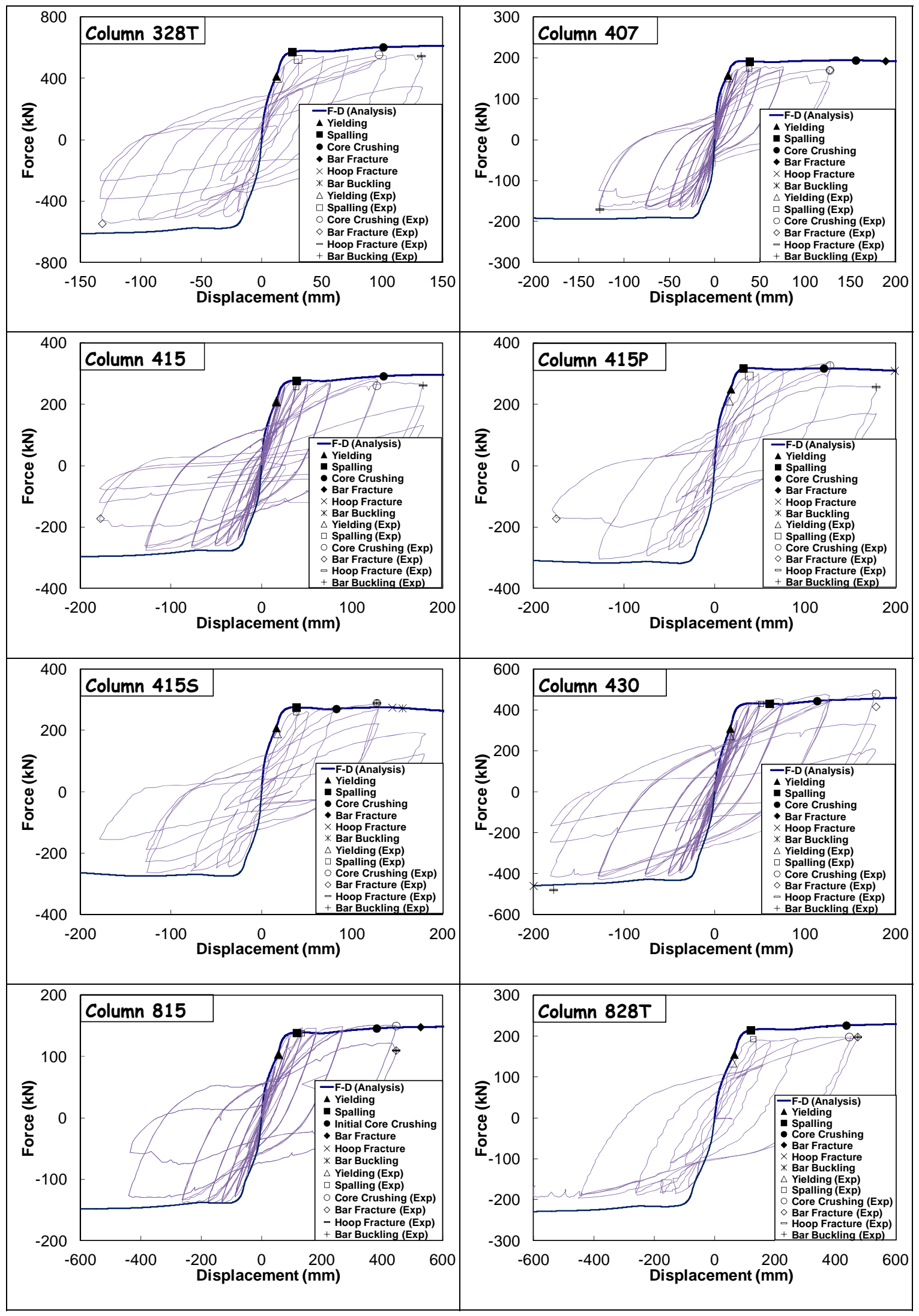

Figure 2. Comparison between experimental results and analytical investigation 


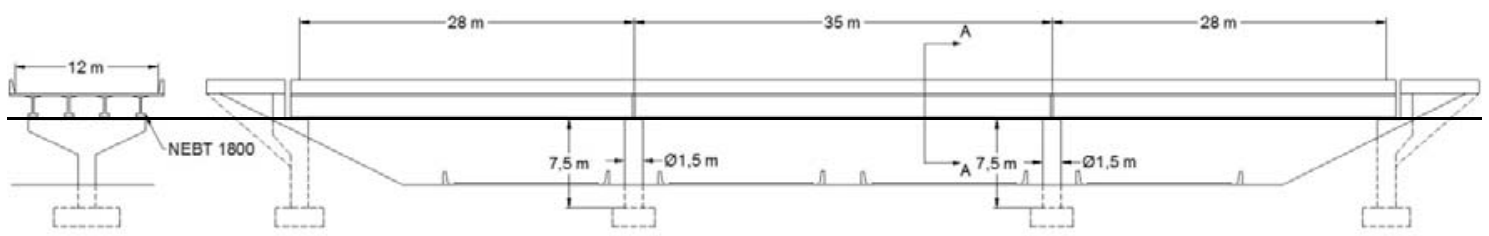

Figure 3. Typical 4-span Highway Bridge

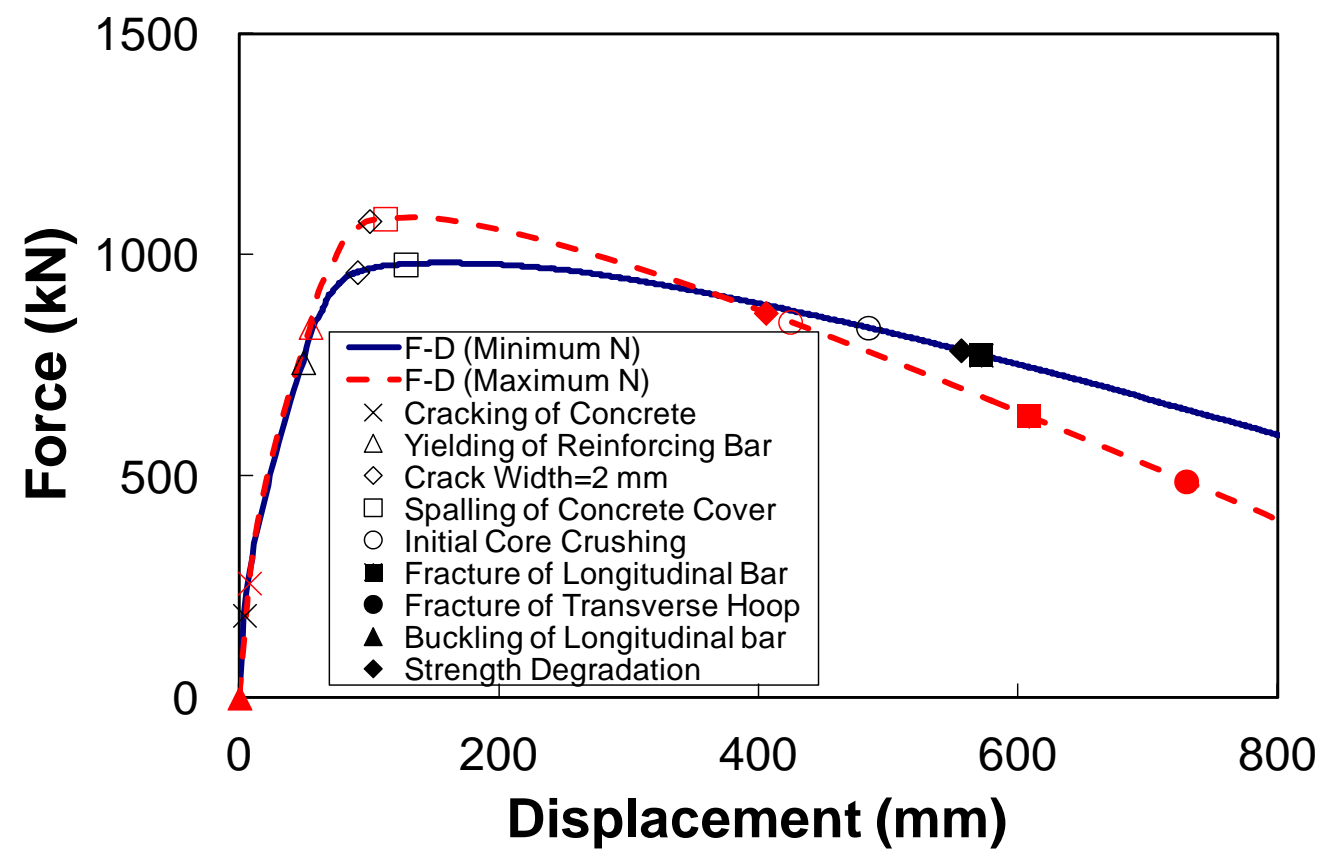

(a) Force-Displacement response 


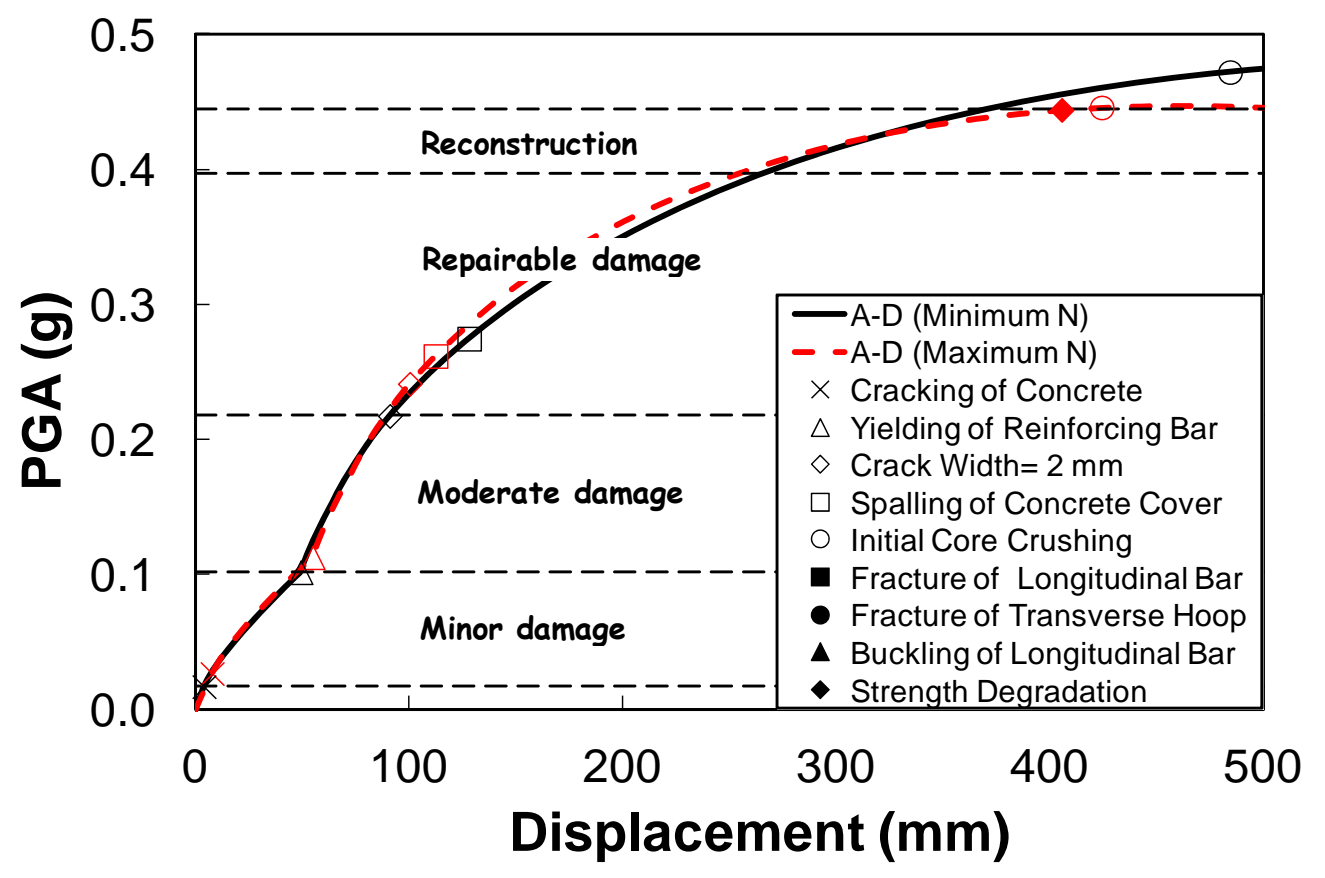

(b) PGA-Displacement response

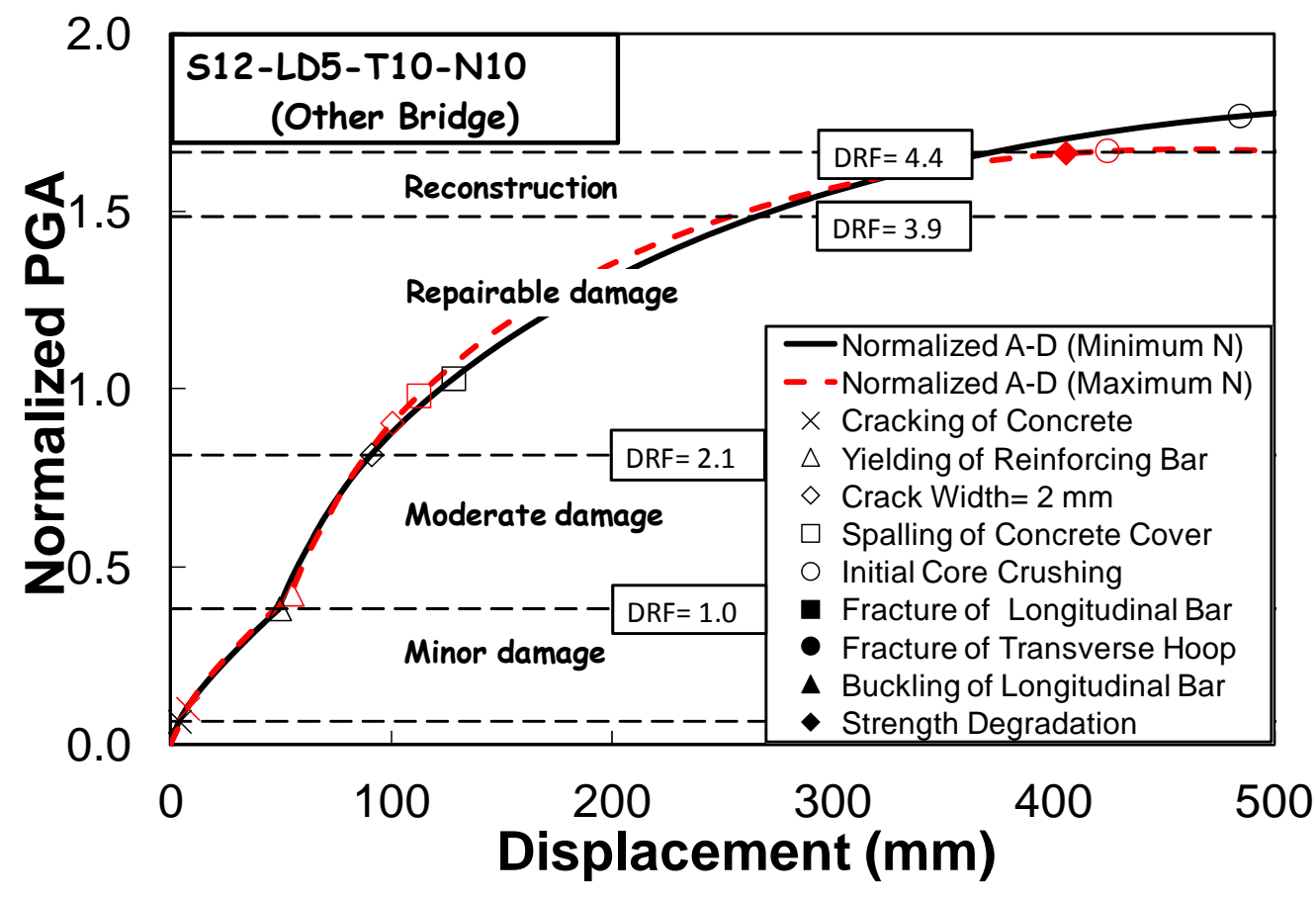

(c) Normalized PGA-displacement response (Other Bridge) 


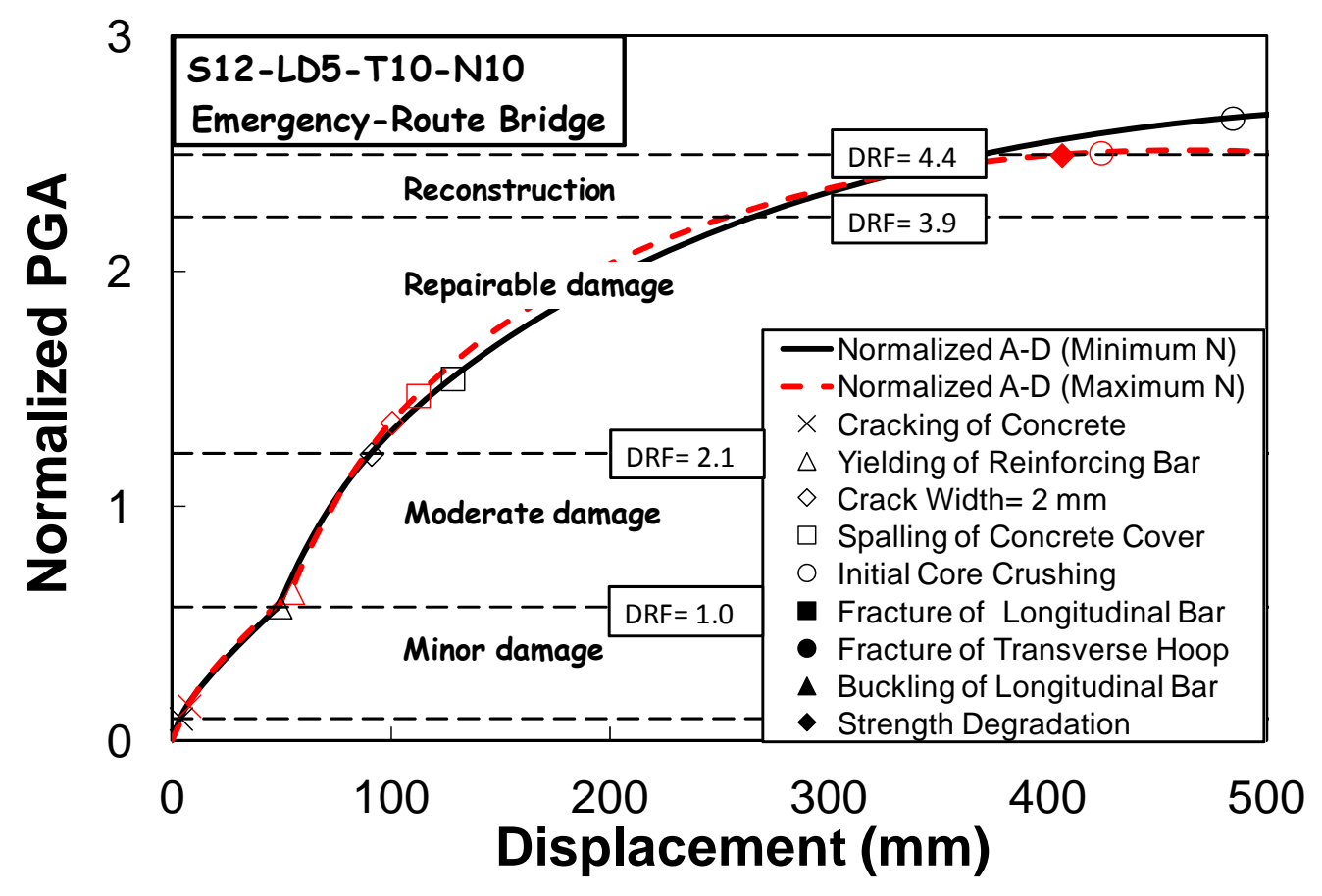

(d) Normalized PGA-displacement response (Emergency Route Bridge)

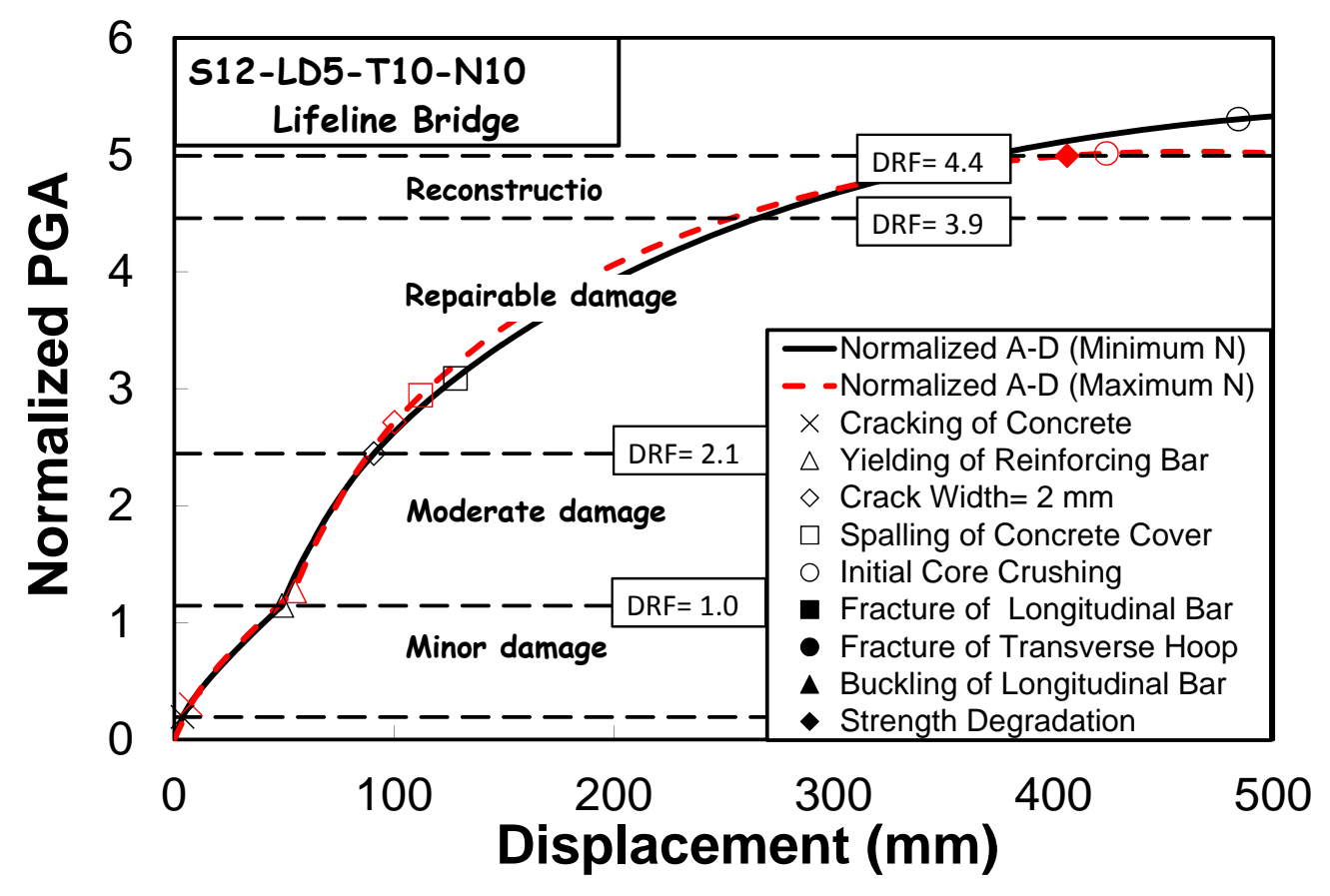

(e) Normalized PGA-displacement response (Lifeline Bridge)

Figure 4. Seismic performance of a typical bridge (S12-LD5-T10-N10 in Table 3) designed according to CHBDC 